\title{
Genetic conservation in Parkia biglobosa (Fabaceae: Mimosoideae) - what do we know?
}

\author{
D. Lompo ${ }^{1,2}$, B. Vinceti ${ }^{3}$, H. Gaisberger ${ }^{3}$, H. Konrad ${ }^{2}$, J. Duminil ${ }^{4,5,6}$, M. Ouedraogo ${ }^{1}$, S. Sina ${ }^{1}$, \\ T. Geburek ${ }^{2 *}$
}

${ }^{1}$ Centre National de Semences Forestières, 01 BP 2682 Ouagadougou 01, Burkina Faso

${ }^{2}$ Austrian Research Centre for Forests, Department of Forest Genetics, Seckendorff-Gudent-Weg 8, 1131 Vienna, Austria

${ }^{3}$ Bioversity International, Via dei Tre Denari, 472/a, Fiumicino Rome, Italy

${ }^{4}$ Bioversity International, Sub-Regional Office for Central Africa, P.O. Box 2008 Messa, Yaoundé, Cameroon

${ }^{5}$ Service Evolution Biologique et Ecologie, CP160/12, Faculté des Sciences, Université Libre de Bruxelles, 50 Av. F. Roosevelt, 1050 Brussels, Belgium

${ }^{6}$ Institut de Recherche pour le Développement, UMR-DIADE, BP 64501, 34394 Montpellier, France

* Corresponding author:T. Geburek, E-mail: thomas.geburek@bfw.gv.at

\begin{abstract}
The medicinal and food tree species Parkia biglobosa (Fabaceae: Mimosoideae) is widespread in the Sudanian savannahs of sub-Saharan Africa, where it has a strong socio-cultural and economic importance. Populations of this species are highly threatened in large parts of its range due to overexploitation and environmental degradation. In the light of climatic changes, safeguarding the genetic diversity of the species is crucial to foster adaptation and to support its long-term survival. Genetic insight is also relevant to guide sustainable harvesting. This paper has the objective to review information on the species' geographic distribution, reproductive biology, genetic characteristics and existing conservation practices, and to identify knowledge gaps to orientate future conservation and research focus. The literature review revealed that the species is mainly outcrossed and is pollinated by a diversity of vectors, including bats that allow long-pollen dispersal. When bats are absent, pollination is mainly carried out by honey bees and stingless bees and in such case pollen-mediated gene flow is relatively restricted. Data of a large-scale genetic study based on allozyme markers showing a moderate genetic differentiation among populations were reanalyzed using an inverse distance weighted interpolation function. Three distinctive regions of diversity based on allelic richness and expected heterozygosity were identified. Finally, we discuss future challenges for genetic conservation by emphasizing the need to use both neutral and adaptive markers in future research.
\end{abstract}

Key words: Parkia biglobosa, conservation, distribution, reproductive biology, sub-Saharan Africa.

\section{Introduction}

Parkia biglobosa (Jacq.) G. Don is a highly valued multipurpose tree species native to African savannahs with a large distribution range extending from Senegal to Uganda (Hopkins, 1983; Hall et al., 1997). Commonly called "Néré" or "African locust bean" it is one of the most important agroforestry tree species in West Africa (Eyog Matig et al., 2002; Nikiema, 2005). It is known as a multiple purpose tree widely used for medicinal and food purposes (Ouedraogo, 1995; Hall et al., 1997). Seeds, bark, roots and flowers of $P$. biglobosa are used to treat more than 80 diseases and ailments in West Africa (Ouedraogo, 1995; Nacoulma-Ouedraogo, 1996; Dedehou et al., 2016). Fermented seeds, called "soumbala" or "dawadawa" are used as condiment, which is also well-known for its ability to decrease hypertension (Ognatan et al., 2011). The sweet pulp of pods is a source of energy and nutrients (rich in glucids, proteins, carotenoids, vitamins A, B, C, and oligo-elements), and is important as nutritional and mineral supplement (Omojola et al., 2011; Dahouenon-Ahoussi et al., 2012; ljarotimi and Keshinro, 2012). The species is melliferous and widely valued in traditional beekeeping (Nombré et al., 2009; Schweitzer et al., 2014). Due to the high demand of its products, $P$. biglobosa is subject to unsustainable exploitation, lack of regeneration and ageing (Ræbild et al., 2012), with some tree populations disappearing or declining in density (Ouedraogo, 1995). Furthermore, improved tree management practices for $P$. biglobosa, such as direct sowing, protection of natural regeneration and planting, are currently not sufficiently promoted (Ræbild et al., 2012).

The conservation and sustainable use of genetic resources are critical to maintain tree resource availability in the long run, especially in the face of significant environmental changes. A 
conservation strategy is based on complementary in situ and ex situ conservation, integrated in a way that relates to the state of tree resources, the objectives of the strategy, and the financial resources available. In situ conservation is primarily focused on conserving the species in its natural environment by preserving its adaptation potential over the long term (FAO et al., 2001), while ex situ strategies are based on creating gene banks or field collections, transferring genetic resources off site, for the purpose of conservation or breeding (Dunster, 1996). Although P. biglobosa is officially protected by national legislation in Burkina Faso and in other West African countries (Eyog Matig et al., 2002) and cutting is prohibited, genetic conservation efforts need to be strengthened. A sound conservation strategy for P. biglobosa and the promotion of its sustainable management should be based on scientific information about threats as well as ecological and genetic processes affecting this species. We felt the need to review and compile relevant scientific findings on this species, published after the monographic work by Hall et al. (1997). In this paper we (i) review existing knowledge on the spatial distribution of the species, its reproductive biology, its genetic characterization and experiences in conservation of its genetic resources in Burkina Faso, with a particular focus on the activities implemented by the national tree seed centre (the "Centre National de Semences Forestières", hereafter CNSF) (Ouedraogo, 1995; Hall et al., 1997, Teklehaimanot, 1997; Sina, 2006, Ouedraogo, 2015). We also (ii) present a new analysis of allozyme data published by Sina (2006) and (iii) identify main research gaps.

\section{Natural range of P. biglobosa}

The geographic distribution of P. biglobosa has been described in a range map by Hall et al. (1997) showing geographic boundaries overlapped with climatic zones (Figure 1). The natural range extends over 20 African countries north of the equator. The species is mainly found in African savannahs, particularly in the Sudanian vegetation zone, partially in the drier, more northern Sahelian zone and the wetter, more southern Guinean zone. The range covers different habitats usually on deep loamy and sandy soils (Arbonnier, 2004) with annual rainfall varying between $700 \mathrm{~mm}$ in the North to $2,600 \mathrm{~mm}$ in the South and exceptional levels up to 4,500 $\mathrm{mm}$ in Sierra-Leone and Guinea (Hall et al., 1997). Tree population density of $P$. biglobosa varies considerably. In the Central African Republic, densities of up to 40 trees per hectare have been reported (Depommier and Fernandes, 1985), while in Burkina Faso, located in the centre of species' range, density varies between less than one tree per hectare in the sub-Sahelian zone to up to 25 trees per hectare in the southern part of the Sudanian zone (Ouedraogo, 1995). Due to the expansion of agriculture and pasture land, urbanization, mining, and also the vulnerability of the species to global environmental changes (Bouda et al., 2013), significant changes in the distribution range of $P$. biglobosa may have taken place during the last 20 years, since occurrence data were assembled for the first time (Hall et al., 1997).

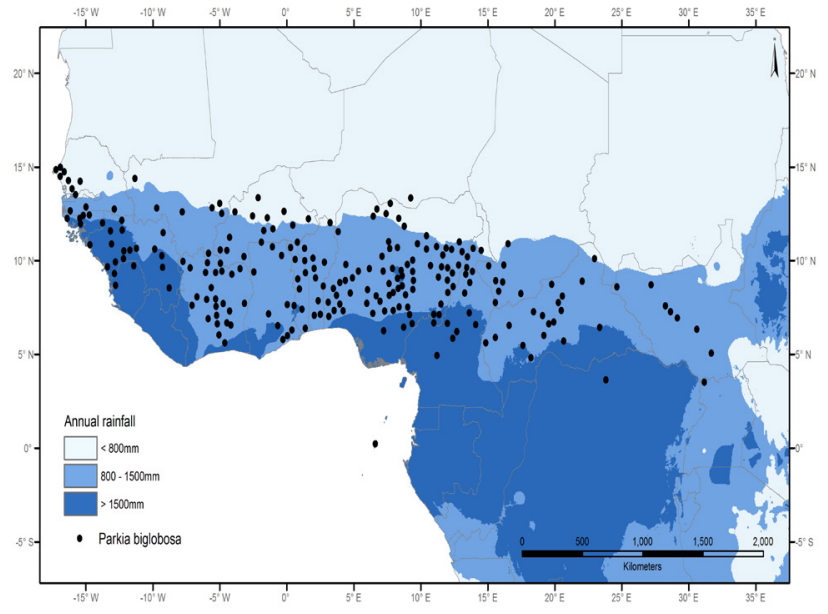

Figure 1

Geographic distribution of Parkia biglobosa in relation to annual rainfall (adapted from Hall et al. 1997)

\section{Floral biology and mating system}

P. biglobosa is a monoecious species. The inflorescence, well described by Hopkins (1983), Ouedraogo (1995) and Lassen et al. (2012), has bright red flowers, forming a capitulum in a large apical ball and a basal constricted receptacle. Different types of flowers are found in the hermaphroditic capitulum. Hopkins (1983) estimated that a capitulum has approximately 2,200 fertile female flowers in the ball-shaped part, 80 staminoid (male) flowers located close to the peduncle and 260 infertile nectar flowers in the ring producing nectar. Despite the coexistence of such a high number of fertile flowers in a single inflorescence, only up to 25 pods are found on an infructescence (Ouedraogo, 1995). Within the crown of a single tree, the capitula tend to show different stages of flower development. Hopkins (1983) and Ouedraogo (1995) reported that flowers of the same capitulum will only be fertile during a single night. Protandry, i.e. early flowering of male and late flowering of female reproductive organs, is found as a mechanism to reduce or even totally avoid selfing (Ouedraogo, 1995). Controlled pollination studies have shown that forced self-pollination results in healthy seeds, however, a certain proportion of seeds per pod were aborted. Hence, self-fertilization is possible, probably through geitonogamy (Lassen et al., 2012). Based on controlled crossing experiments, Ouedraogo (1995) estimated a selfing rate of $5 \%$. A very similar level of selfing was later confirmed by Sina (2006). In fact, he studied the mating system in two populations at Bissighin $\left(\mathrm{W} 1.61^{\circ} ; \mathrm{N} 12.30^{\circ}\right)$ and Nagare (W1.53 $\mathrm{N} 12.30^{\circ}$ ) in Burkina Faso, examining 153 and 209 mature trees, respectively. In both populations, in two consecutive years, flowering was well synchronized and the average multilocus estimates resulted in high outcrossing rates of 0.941 and 0.981 , respectively. Biparental inbreeding inferred from the difference between single-locus and multilocus estimates of selfing was 0 at Nagare and 0.026 and 0.086 at Bissighin in two consecutive years showing that less than $9 \%$ of matings involved close relatives. High paternity correlations indicated that 
mother trees received pollen from only few pollen donors (Lassen et al., 2014). Pollen is released in polyads, i.e. packages of 16 or 32 pollen grains (Baker and Harris, 1957). Polyads probably confer a selective advantage as they provide an efficient way for animal-mediated pollen transport (Kenrick and Knox, 1982), and honey bees are very efficient carriers of polyads compared to other insects pollinating $P$. biglobosa (Lassen et al., 2012). A single pod may contain up to 24 seeds (Ouedraogo, 1995), but commonly the number is lower; $16.5 \pm 5.2$ seeds per pod were reported by Lassen et al. (2014). Due to the large polyads and the small size of the stigma, Hopkins (1984) hypothesized that one or two pollen grains sire all ovules of a single pod. Indeed, Lassen et al. (2014) provided evidence that one pollen donor sires all the ovules in a single pod. Hence, each pod contains a full-sib-family. This needs to be taken into account, whenever genetic resources are sampled. This should be also considered by keeping records of pods and mother trees when quantitative genetic parameters are estimated in field trials. In the southern parts of the species' distribution the onset of flowering starts in November/December, while in the northern parts the flowering peaks in March. Along an eastwest gradient, flowering and fruiting start earlier in the west and lag two weeks behind in the east (Ouedraogo, 1995).

\section{Pollinators}

P. biglobosa's seed set is related to pollinator richness and abundance (Lassen, 2016). About thirty potential pollinating species were recorded to visit $P$. biglobosa flowers (Table 1). However, the genus Parkia has been described as chiropterophilous (Baker and Harris, 1957; Ouedraogo, 1995; Lassen et al., 2012), because the structure of the inflorescence is well adapted to pollination by bats. The main pollinating species are megabats belonging to the family Pteropodidae: Eidolon helvum, Epomophorus gambianus, Micropteropus pusillus and Nanonycheris veldkampi. Pettersson and Knudsen (2001) reported that the floral scent and the nectar production are high in the earlier part of nocturnal anthesis and decrease during the visitation of megabats. Megabats normally land singly or in groups, at dusk or dawn, in the upper part of the crown, and visit the capitula for only few seconds or minutes. For instance, Hopkins (1983) observed Micropteropus pusillus singly landing on capitula only after dark, for no more than two seconds before flying off to visit other capitula of the same or another tree. This behaviour probably promotes cross-pollination.

In addition to bats, insects are important pollinators of $P$. biglobosa, particularly honey bees and stingless bees (Table 1). In areas where bats are rare or even absent, for instance in the northern part of Burkina Faso, honey bees are the most important pollinators (Ouedraogo, 1995, Lassen, 2016). Controlled pollination experiments carried out in the Gambia (Lassen et al., 2012), indicated that honey bees, such as Apis mellifera adansonii, were the most important pollinating insects; however, even small, few millimeters long stingless bees (Hypotrigona spp.) contributed successfully to pollination. Other insects, such as pollen and nectar-lapping visitors, are also attracted by the colour and scent of the flowers. Some occasional visitors are acting more like pollen and nectar thieves; ants, wasps and beetles seem to be inefficient pollinators (Ouedraogo, 1995; Lassen et al., 2012), and their role in P. biglobosa pollination is probably limited. Birds, particularly sunbirds from the Nectariniidae, Pycnonotidae and Zosteropidae families, have been recorded visiting capitula (Ouedraogo, 1995). Both birds and insects were found visiting inflorescences only at the beginning and at the end of the anthesis and therefore their contribution to pollination is likely negligible.

\section{Pollen and seed dispersal distances}

Long-distance pollen dispersal ensures genetic connectivity even in fragmented and low-density populations of tree species (Kamm et al., 2009). The dispersal distance of pollen might differ among pollinator species. Pollinators like megabats probably disseminate pollen over long distances. The straw-coloured fruit bat (Eidolon helvum), an important pollinator for $P$. biglobosa, is able to fly locally up to $10-20 \mathrm{~km}$ day- 1 , while some migrants typically travel $90 \mathrm{~km}$ day-1. Bee-mediated gene flow is a priori more limited than bats in terms of distance. The daily mean total foraging distance for the African honey bee species Apis mellifera scutellata, was found to be 1,073 $\pm 52 \mathrm{~m}$ (Schneider and Hall, 1997). A pollination experiment carried out by Lassen (2016) in two sites in Burkina Faso showed mean pollination distances varying from $283 \mathrm{~m}$ when flowers were accessible to all pollinators, to $183 \mathrm{~m}$ when bats were excluded and to $173 \mathrm{~m}$ when bats, honey bees and other large insects were excluded. Thus, bats seem to be effective long-distance pollinators, while honey bees are probably mainly mediating short-distance gene flow via pollen.

The sweet pulp of $P$. biglobosa pods contributes to the diet of animals and represents an important complement to the diet of farmers, especially but not exclusively during food shortage periods. Seeds are mainly disseminated by primates, rodents and birds. Pods are a favourite food of chimpanzees (Pan troglodytes) and baboons (Papio anubis) in West Africa (Ouedraogo, 1995; Lassen et al., 2012). Different species of rodents (e.g. squirrels and rabbits) have been recorded eating seeds, while birds such as parrots (Poicephalus senegalus) have been found to feed on pods (Ouedraogo, 1995) and may contribute to dissemination also through their faeces. In the agroforestry parklands of West Africa humans are likely to be agents of seed dissemination. Pods ripen at the beginning of the rainy season when some agricultural products, especially cereals, are not available. Pods and seeds are traded over large distances and may fall on the ground during transportation. In the recent past, large stands have been reported along the Abidjan-Niger railway, probably established as a result of seed dissemination by workers and train passengers (Ouedraogo, 1995; Sina, 2006).

The indirect estimate of gene flow based on the genetic population differentiation of 64 populations, distributed across $P$. biglobosa's range, was only 1.61 migrants per generation $(\mathrm{Nm})$ (Sina, 2006), lower than the average $\mathrm{Nm}$ value of 2.28 
Table 1

List of bats and insect species recorded as potential pollinators visiting the flowers of Parkia biglobosa. Abbreviations: 1=Ouedraogo (1995), 2=Odebiyi et al. (2004), 3=Hopkins (1983), 4=Lassen et al. (2012), 5=Lassen (2016), 6=Pettet (1977), +++ = very high, $++=$ high, $?=$ incertain

\begin{tabular}{|c|c|c|c|c|c|c|c|c|}
\hline \multirow{2}{*}{ Species } & \multirow{2}{*}{ Common name } & \multirow{2}{*}{ Family } & \multicolumn{4}{|c|}{ Period of visit } & \multirow{2}{*}{$\begin{array}{l}\text { Effective- } \\
\text { ness in } \\
\text { pollination }\end{array}$} & \multirow{2}{*}{$\begin{array}{l}\text { Refer- } \\
\text { ences }\end{array}$} \\
\hline & & & Dusk & Night & Dawn & Day & & \\
\hline Eidolon helvum & Straw-coloured fruit bat & Pteropodidae & $x$ & $x$ & $x$ & & +++ & $1 ; 3$ \\
\hline Epomophorus gambianus & Gambian epauletted fruit bat & Pteropodidae & $x$ & $x$ & $x$ & & +++ & 1 \\
\hline Epomops franqueti & Franquet's epauletted bat & Pteropodidae & $x$ & $x$ & $x$ & & +++ & 2 \\
\hline Hypsignathus monstrosus & Hammer-headed bat or the big-lipped bat & Pteropodidae & $x$ & $x$ & $x$ & & +++ & 1 \\
\hline Lissonycteris angolensis & Angolan fruit bat or Angolan rousette & Pteropodidae & $x$ & $x$ & $x$ & & +++ & 1 \\
\hline Micropteropus pusillus & Peter's dwarf epauletted fruit bat & Pteropodidae & $x$ & $x$ & $x$ & & +++ & $1 ; 3$ \\
\hline Nanonycteris veldkampii & Veldkamp's bat & Pteropodidae & $x$ & $x$ & & & +++ & 3 \\
\hline Apis mellifera adansonii & Honey bees & Apidae & $x$ & & $x$ & & +++ & $1 ; 2 ; 4$ \\
\hline Apis mellifera jemenitica & Honey bees & Apidae & & & $x$ & & +++ & 5 \\
\hline Compsomelissa borneri & & Apidae & & & $x$ & & ++ & 5 \\
\hline Hypotrigona sp. & Stingless bees & Apidae-Apinae & & & $x$ & $x$ & ++ & $4 ; 5$ \\
\hline Bruchinae sp. & & Chrysomelidae & & & & $x$ & $?$ & 5 \\
\hline Spermophagus sp. & & Chrysomelidae-Bruchinae & & & & $x$ & $?$ & 5 \\
\hline $\begin{array}{l}\text { Afromaculepta demma- } \\
\text { culata }\end{array}$ & & Chrysomelidae-Galerucinae & & & & $x$ & $?$ & 5 \\
\hline Coccinella sp. & & Coccinellidae & $x$ & & $x$ & & $?$ & 1 \\
\hline Camponotus spp. & Carpenter ants & Formicidae-Formicidae & & $\mathrm{x}$ & & & $?$ & $4 ; 5$ \\
\hline Lepisiota sp. & & Formicidae-Formicidae & & $x$ & & & $?$ & 4 \\
\hline Crematogaster sp. & Acrobat ants & Formicidae-Myrmicinae & & & & $x$ & $?$ & 5 \\
\hline Atopomyrmex sp. & & Formicidae-Myrmicinae & & $x$ & & & $?$ & 4 \\
\hline Monomorium pharaonis & Pharaoh ant & Formicidae-Myrmicinae & $x$ & & & $x$ & $?$ & 1 \\
\hline Pogoniulus chrysoconus & Yellow-fronted tinkerbird & Lybiidae & $x$ & & & $x$ & $?$ & 1 \\
\hline Hycleus sp. & & Meloidae & & & & $\mathrm{x}$ & $?$ & 4 \\
\hline Nectarinia senegalensis & Scarlet-chested sunbird & Nectariniidae & $x$ & & $x$ & & $?$ & 6 \\
\hline Anthreptes platura & Pygmy sunbird & Nectariniidae & $x$ & & $x$ & & $?$ & 6 \\
\hline Pycnonotus barbatus & Common bulbul & Pycnonotidae & $x$ & & $x$ & & $?$ & 6 \\
\hline Sarcophaga carnaria & Common flesh fly & Sarcophagidae & $x$ & & & $x$ & $?$ & 1 \\
\hline Ropalidia sp. & Aper-wasps & Vespidae-Polistinae & & & & $x$ & $?$ & 4 \\
\hline Zosterops senegalensis & Senegal white-eyes & Zosteropidae & $x$ & & $x$ & & $?$ & 6 \\
\hline
\end{tabular}

recorded for other animal-pollinated woody species (Hamrick et al., 1992) and considerably lower than estimates obtained for Vitellaria paradoxa ( $\mathrm{Nm}=5.07$; Sanou et al., 2005), often found in sympatry with P. biglobosa. However, the indirect estimates of gene flow based on $\mathrm{F}_{\mathrm{ST}}$ should be interpreted with caution as the method is based on assumptions which not always are fulfilled in real populations (Whitlock and McCauley, 1999).

\section{Quantitative genetic variation}

The effects of drought stress on growth and survival of seven provenances of $P$. biglobosa seedlings originating from Burkina
Faso and Mali were studied in a nursery experiment (Bouda et al., 2013). Although significant interactions between different water regimes and provenances were found, it was not possible, based on growth traits including fresh and dry weight or shoot-to-root dry weight ratios, to clearly separate provenances according to their geographic origin or to climatic parameters. A substantial genetic differentiation in growth traits and survival rate, based on the coefficient of variation among 25 provenances (13-yr old) from West and Central Africa was reported (Ouedraogo et al., 2012). Relationships between some geographical parameters (longitude, latitude) and traits (height, basal area and survival) were significant. Reaction norms indicated that the highest survival can be expected from local plant material, while vegetative growth may be 
slightly improved by shifting provenances to the east for up to $5^{\circ}$ of longitude. Previous assessments of the same provenance trials by Oni (2004) on five-year old trees also indicated that eastern provenances grew generally better than the central and western provenances. Leaf morphology was found to vary largely and a significant correlation was recorded between the length of leaflets and longitude ( $r=0.92)$ (Ouedraogo, 2015). Thus, from west to east, the size of leaflets increases in P. biglobosa populations from Senegal to Nigeria and Cameroon. Moreover, leaves of western populations were characterized by a finer structure, showing smaller and more leaflets than the eastern ones. The east-west cline in leaf traits in P. biglobosa supports similar findings reported by Hopkins (1983) based on 85 herbarium specimens. Clinal variation patterns were also observed by Millogo (2014) in seed morphological traits (length, width, thickness, weight) in a sample of 246 seed trees from 18 provenances, from across four countries (Benin, Cameroon, Guinea and Ivory Coast) in the humid climate zone. He found a longitudinal variation of length, thickness and width of seed traits. From western to eastern provenances, seeds become flatter, larger, longer, and heavier, forming two distinct groups (West African and Central African provenances).

Quantitative variation of $P$. biglobosa populations indicates a potential for domestication, through selection and breeding, with possible positive effects on rural livelihoods (Teklehaimanot, 2004). Unfortunately knowledge on heritability of key traits in $P$. biglobosa is very limited, as only broad-sense heritabilities $\left(\mathrm{H}^{2}\right)$ for different growth traits in Nigerian seedlings $\left(\mathrm{H}^{2}\right.$ plant height $=0.54 ; \mathrm{H}^{2}$ fresh root weight $=0.13$ ) were analysed (Adesoye et al., 2013). However, these estimates should be considered with caution, as methods were not clearly described.

\section{Marker-based genetic diversity and new analysis of allozyme data}

There are very few marker-based studies at hand assessing genetic diversity of $P$. biglobosa. A study using Random Amplified Polymorphic DNA (RAPD) markers revealed a weak genetic diversity $\left(H_{\mathrm{E}}=0.05-0.18\right)$ in 23 open-pollinated families of $P$. biglobosa in Nigeria (Amusa et al., 2014). However, due to the small scale of the sampling, meaningful conclusions for the whole species cannot be drawn. A large-scale study using eight allozyme loci was conducted by Sina (2006) examining open-pollinated seeds from 64 populations across 11 Western and Central African countries. Observed heterozygosity $\left(H_{0}\right)$ and expected heterozygosity $\left(H_{\mathrm{E}}\right)$ were 0.26 and 0.34 , respectively. In some populations, moderate excess of homozygotes compared to Hardy-Weinberg expectations was observed. As embryos were used for this genetic inventory, this excess is probably due to selfing and will disappear during later ontogenetic stages as it is typically found in tree species with mixedmating systems (Rink et al., 1989). With regard to the genetic differentiation index $\left(\mathrm{F}_{\mathrm{ST}}\right)$, a small to moderate estimate of 0.13 was obtained (Sina, 2006) compared to tropical tree species (e.g., $\mathrm{F}_{\mathrm{ST}}=0.177$; Dick et al., 2008).
A re-analysis of allozyme data, originally collected by Sina (2006), was carried out in order to visualise the geographic patterns of allelic richness $(A)$ and expected heterozygosity $\left(\mathrm{H}_{\mathrm{E}}\right)$ of the 64 populations of $P$. biglobosa. The inverse distance weighted (IDW) interpolation function (Pollegioni et al., 2014) was implemented in ArcGIS 10.1 (ESRI, Redlands, CA, USA) and applied to the allozyme dataset. As described by Murphy et al. (2008), a continuous surface map was created using a linearly weighted combination of all the 64 sample points. The interpolation was limited to the area of a convex hull polygon that encloses the sample points. This approach ensures that each input point has a local influence that diminishes with distance in order to minimize the effect of irregular sampling. The results obtained shows three distinguishable regions of diversity based both on allelic richness (Figure 2) and expected heterozygosity (Figure 3). A high allozyme diversity was found in the centre of West Africa (Benin, Burkina Faso, Ghana, Ivory Coast, Mali and Togo), while lower allozyme diversity was located in marginal parts of the range in West Africa (Senegal, Guinea) and Central Africa (Cameroon), including populations from Niger and Nigeria. Higher genetic allozyme diversity was also estimated for specific populations in Guinea, Nigeria and Senegal (Figures 2 and 3). However, these patterns are not detailed enough to develop conservation strategies, calling for further characterization of species' genetic diversity distribution.

\section{Experience of CNSF in genetic conservation}

Approaches based on both in situ and ex situ conservation were implemented by CNSF in order to conserve the genetic resources of $P$. biglobosa. To guide seed transfer, six seed zones (Figure 4) were delineated in Burkina Faso for all tree species taking into consideration ecological, climatic and administrative information.

Regarding in situ conservation, 48 stands of $P$. biglobosa were identified, phenotypically characterized and are managed in their natural habitat to be used as seed sources (Figure 4). They are identified only in three seed zones due to absence or low density of stands in northern areas. The monitoring and management of seed stands involve local communities to ensure that individual trees forming these stands are conserved and managed sustainably. Each seed stand includes between 30 and 50 reproductive trees and covers an area between ca. 10 ha to 50 ha; large seed stands of more than 100 ha were also identified mainly in two seed zones (South Sudanian and Comoe). Certain seed sources are efficiently safeguarded due to their location within protected areas (Figure 4), although the species is officially protected across the whole country.

With regard to ex situ conservation efforts, a range-wide collection of seeds of P. biglobosa was established through two successive collection campaigns undertaken in 1989 (Ouedraogo, 1995) and 1993 (Teklehaimanot, 1997) by CNSF and partners. These two collections involved seed sources from ten countries in West Africa (Benin, Burkina Faso, Ghana, Guinea, Ivory Coast, Mali, Niger, Nigeria, Senegal and Togo) and two countries in Central Africa (Cameroon, Chad). Seed lots were 
collected and stored separately by maternal tree at the CNSF seed bank. In addition, ex situ activities were carried out focusing on the establishment of field trials at Gonse (W1.33 ; $\left.\mathrm{N} 12.42^{\circ}\right)$ and Dinderesso $\left(\mathrm{W} 4.58^{\circ} ; \mathrm{N} 11.30^{\circ}\right)$ in Burkina Faso. The experiments included plantations, provenance and progeny trials. A high mortality rate was recorded even for local provenances, showing potential limitations in using the species for plantation. Furthermore, an assessment of these provenance trials 13 years after their establishment showed mean survival rates of $35 \%$ and $61 \%$ at Gonse and Dinderesso, respectively (Ouedraogo et al., 2012). Two local provenances had lower survival rates ( $29 \%$ and $57 \%$, respectively) compared to the mean performance of all provenances in the two trials (Ouedraogo et al., 2012).

Optimal seed harvesting procedures were developed. Seed viability, seed behaviour, seed storage conditions were tested, and physiological studies on seedling's growth were carried out. Results showed that seeds of $P$. biglobosa tolerate desiccation at a low moisture content (5\%) and maintain their high viability after storage in freezing temperatures; therefore they can be considered as orthodox seeds (Hong and Ellis 1996). Fresh seeds reach easily a germination rate of $95 \%$ after pre-treatment with concentrated sulphuric acid (97\%), which breaks seed dormancy. However, after prolonged storage, seeds show declining germination, generally caused by a progressive absorption of moisture. A recent evaluation of seeds stored for 20 years showed a significant loss of germination rate, declined to just $15 \%$ from the initial values recorded for freshly collected seeds (Millogo, 2014). Exceptionally, Sina (2006) reported for one accession a sustained germination rate of $95 \%$ after 11 years of storage at $4^{\circ} \mathrm{C}$ and $5 \%$ of moisture content. Vegetative propagation using mature tissues is difficult (Teklehaimanot, 2004, Ræbild et al., 2011). Consequently, direct sowing is the most practical technique used to rejuvenate and to improve traditional agroforestry systems. Breeding trials of 10-year old seedlings of $P$. biglobosa showed that the species has a faster growth than other agroforestry species, such as Acacia albida (syn. Faidherbia albida) and Ziziphus mauritiana (Lompo, 1999). The average collar diameter and total height of 10-year old individuals of $P$. biglobosa were estimated at $11.72 \mathrm{~cm}$ and $4.54 \mathrm{~m}$ respectively (Lompo, 1999). The relatively rapid growth and easy propagation by seeds offer opportunities to promote the conservation and sustainable use of the species.

\section{Research gaps for genetic conservation}

While the floral biology and mating system are well documented, research addressing gene flow would enable to improve understanding of fragmentation effects and management practices. Global environmental change, habitat loss and wide use of pesticides are main causes of pollinator decline. In fact, species richness and abundance of some pollinators in West Africa, such as bats, have been observed to be decreasing due to lack of suitable habitats and declining food resources (Fahr, 2008; Kangoyé et al., 2015). Therefore, further population genetic studies, especially designed to assess the species

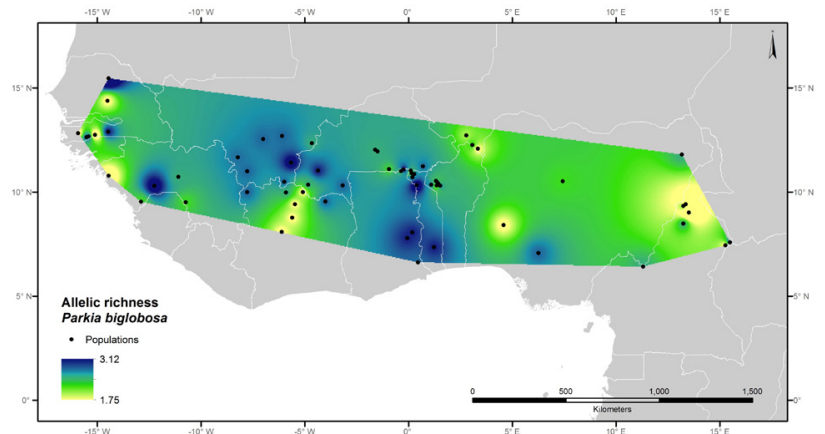

Figure 2

IDW interpolation of allelic richness (AR) calculated for 64 Parkia biglobosa populations using eight allozyme loci and restricted to a convex hull polygon that encloses the sample points. The colour gradient indicates the level of allelic richness.

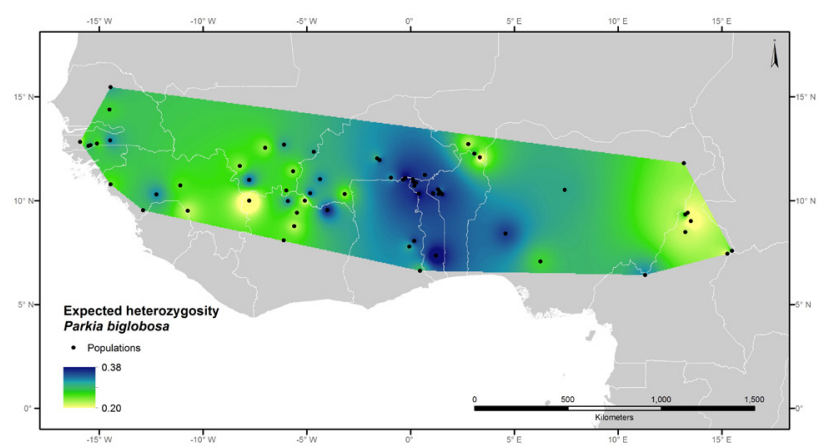

Figure 3

IDW interpolation of expected heterozygosity (HE) calculated for 64 Parkia biglobosa populations using eight allozyme loci and restricted to a convex hull polygon that encloses the sample points. The colour gradient indicates the level of expected heterozygosity.

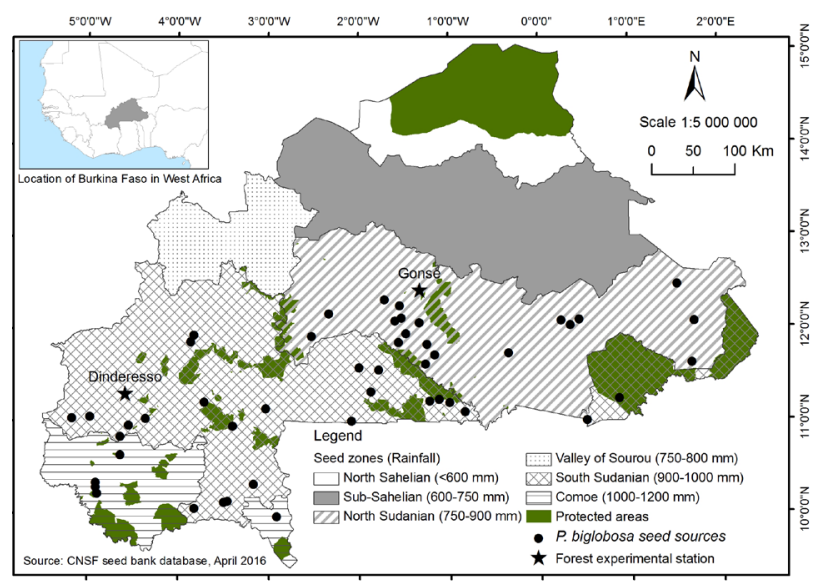

Figure 4

Distribution of Parkia biglobosa seed sources across the identified seed zones in Burkina Faso, West Africa. 
vulnerability to fragmentation and the influence of land use changes on its viability, are needed.

Generally, quantitative genetic research is very limited in this species. Sound knowledge on additive genetic variation is not available, response functions of populations are missing but would be extremely helpful in managing genetic resources in view of environmental changes. Both among-population variation based on quantitative data $\left(Q_{S T}\right)$ and effective population sizes are unknown.

Although P. biglobosa seeds are orthodox, they lose their capacity to germinate after 20 years (Millogo, 2014). Cryopreservation of seeds may be a solution (Ahuja, 1986). Vegetative propagation techniques such as cutting, layering and grafting need to be optimized in order to develop clone banks of selected desirable traits.

At regional or country level, a development of seed zones and seed transfer guidelines, using approaches that combine molecular information and multivariate regression trees (Hamman et al., 2011), would effectively contribute to reforestation success in the face of climate change. In addition to ecological and genetic knowledge, we recommend also the inclusion and analysis of social and cultural aspects, such as indigenous knowledge and preferences, in the shaping of future breeding efforts. Considering the wide range of $P$. biglobosa, the development of a multi-country strategy for the conservation and sustainable use of its genetic resources, would need to be coordinated through effective international collaboration.

\section{Acknowledgements}

This article has been made possible thanks to the financial support granted by the Austrian Development Agency for the project on "Threats to food tree species in Burkina Faso", led by Bioversity International (Italy), and thanks to additional support through the CGIAR Research Program on Forests, Trees and Agroforestry. We thank David Millogo, Edith Daboue and all the staff of CNSF for help with the assessment of seed germplasm collection. We are grateful to Dr Anders Ræbild at Department of Geosciences and Natural Resource Management-University of Copenhagen and anonymous reviewers for their valuable suggestions and comments on the manuscript.

\section{References}

Adesoye Al, Ogunremi CO, Aina OO (2013) Genetic variation and heritability of seedlings traits in African locust bean - Parkia biglobosa (Jacq.) R.Br. ex Don. Legume Res 36: 89-97

Ahuja MR (1986) Storage of forest tree germplasm in liquid nitrogen $\left(-196^{\circ} \mathrm{C}\right)$. Silvae Genet 35: 249-151

Amusa O, Adesoye A, Ogunkanmi A, Omoche O, Olowe O, Akinyosoye S, Omodele T (2014) Genetic diversity of Parkia biglobosa from different agroecological zones of Nigeria using RAPD Markers. Inter JBiodiv, 6p https://doi.org/10.1155/2014/457309

Arbonnier M (2004) Trees, shrubs, and lianas of West African dry zones. Paris: $\mathrm{Cl}$ RAD, 573p

Baker HG, Harris BJ (1957) The pollination of Parkia by bats and its attendant evolutionary problems. Evolution11: 449-460 https://doi.org/10.1111/j.1558-5646.1957.tb02916.x
Bouda ZHN, Bayala J, Markussen B, Jensen JS, Ræbild A (2013) Provenance variation in survival, growth and dry matter partitioning of Parkia biglobosa (Jacq.) R.Br. ex G.Don seedlings in response to water stress: Agrofor Syst 87:59-71. https://doi.org/10.1007/s10457-012-9521-9

Dahouenon-Ahoussi E, Adjou ES, Lozes E, Yehouenou LL, Hounye R, Famy N Soumanou MM, Sohounloue DCK (2012) Nutritional and microbiological characterization of pulp powder of locust bean (Parkia biglobosa Benth.) used as a supplement in infant feeding in Northern Benin. Afr J Food Sci 6: 232-238. https://doi.org/10.5897/aifs12.016

Dedehou VFGN, Olounladé PA, Alowanou GG, Azando EVB, Hounzangbé-Adoté $S$ (2016) A review on medicinal plants of Parkia biglobosa (Mimosaceae-Fabaceae) and Pterocarpus erinaceus (Leguminosae-Papilionoidea). JMPS 4(6): 132-137

Depommier D, Fernandes E (1985) Aspects du parc à karités-nérés (Butyrospermum parkii, Parkia biglobosa) dans la région de l'Ouham (République Centrafricaine). Nairobi, ICRAF. $27 \mathrm{p}$

Dick CW, Hardy OJ, Jones FA, Petit RJ (2008) Spatial scales of pollen and seed-mediated gene flow in tropical rain forest trees. Trop PI Biol 1:20-33. https://doi.org/10.1007/s12042-007-9006-6

Dunster JK (1996) Dictionary of Natural Resource Management. CAB International. UBC Press. ISBN $0851991483.363 p$

Eyog Matig O, Gaoué OG, Dossou B (2002) Réseau « Espèces Ligneuses Alimentaires ». Compte rendu de la première réunion du Réseau tenue 11-13 décembre 2000 au CNSF Ouagadougou, Burkina Faso. Institut International des Ressources Phytogénétiques, $235 \mathrm{p}$

Fahr J (2008) Diversity Patterns and Taxonomy of West African Bat Assemblages: Effects of Spatial Scale and Habitat Structure. Ulm University: Ph.D. dissertation, $315 \mathrm{p}$

FAO, DFSC, IPGRI (2001) Forest genetic resources conservation and management. Vol. 2: In managed natural forests and protected areas (in situ). International Plant Genetic Resources Institute, Rome, Italy

Hall JB, Thomlinson HF, Oni PI, Buchy M, Aebischer DP (1997) A monograph of Parkia biglobosa. School of Agricultural and Forest Sciences Publication $\mathrm{N}^{\circ} 9$, Bangor, University of Wales, $107 \mathrm{p}$

Hamann A, Gylander T, Chen P (2011) Developing seed zones and transfer guidelines with multivariate regression trees. Tree Genetics \& Genomes 7:399-408. https://doi.org/10.1007/s11295-010-0341-7

Hamrick JL, Godt MJW, Sherman-Broyles S (1992) Factors influencing levels of genetic diversity in woody plant species. New For 6: 95-124 https://doi.org/10.1007/bf00120641

Hong TD, Ellis RH (1996) A protocol to determine seed storage behaviour. IPGRI Technical Bulletin No. 1. (J.M.M. Engels and J. Toll, vol. eds.) International Plant Genetic Resources Institute, Rome, Italy, 61 p

Hopkins HC (1983) The taxonomy reproductive biology and economic potential of Parkia (Leguminosae: Mimosoïdeae) in Africa and Madagascar. Bot JLinn Soc 87: 135-167. https://doi.org/10.1111/j.1095-8339.1983.tb00987.x

Hopkins HC (1984) Floral biology and pollination ecology of the Neotropical species of Parkia. J Ecol 72: 1-23. https://doi.org/10.2307/2260003

Ijarotimi OS, Keshinro OO, (2012) Comparison between the amino acid, fatty acid, mineral and nutritional quality of raw, germinated and fermented African locust bean (Parkia biglobosa) flour. Acta Sci Pol Technol Aliment 11: 151-165

Kamm U, Rotach P, Gugerli F, Siroky M, Edwards P, Holderegger R (2009). Frequent long-distance gene flow in a rare temperate forest tree (Sorbus domestica) at the landscape scale. Heredity 103: 476-482 https://doi.org/10.1038/hdy.2009.70

Kangoyé NM, Ouéda A, Granjon L, Thiombiano A, Guenda W, Fahr J (2015) Diversity and distribution of bats (Mammalia Chiroptera) in Burkina Faso. Biodiv J $6: 597-632$

Kenrick J, Knox RB. 1982. Function of the polyad in the reproduction of Acacia. Ann Bot 50: 721-727. https://doi.org/10.1093/oxfordjournals.aob.a086414

Lassen KM (2016) Pollination strategies to increase productivity of the African fruit trees Vitellaria paradoxa subsp. paradoxa \& Parkia biglobosa. PhD thesis, University of Copenhagen,Denmark

Lassen KM, Kjær ED, Ouédraogo M, Nielsen LR (2014) Microsatellite primers for Parkia biglobosa (Fabaceae: Mimosoideae) reveal that a single plant sires all seeds per pod. AppIPI Sci 2:1400024. https://doi.org/10.3732/apps.1400024

Lassen KM, Ræbild A, Hansen H, Brødsgaard CJ, Eriksen EN (2012) Bats and bees are pollinating Parkia biglobosa in the Gambia. Agroforest Syst 85: 465-475. https://doi.org/10.1007/s10457-011-9409-0 
Lompo D (1999) Etude sur la croissance de quelques espèces ligneuses en plantation dans la Forêt Classée de Gonsé: Acacia albida Del., Azadirachta indica A. Juss., Eucalyptus camaldulensis Dehnh, Parkia biglobosa (Jacq.) Benth et Ziziphus mauritiana Lam. Mémoire de fin de cycle d'ingénieur de développement rural. IDR/UPB, $61 \mathrm{p}+$ annexes

Millogo AMD (2014) Etude des caractéristiques morphologiques et de la viabilité des semences de Parkia biglobosa (Jacq.) R. Br. ex G. Don. - germoplasme de conservation à long terme à $4^{\circ} \mathrm{C}$. Mémoire de Master, Institut de Développement Rural - Université Polytechnique de Bobo-Dioulasso, $42 \mathrm{p}$

Murphy MA, Evans JS, Cushman SA, Storfer A (2008) Representing genetic variation as continuous surfaces: an approach for identifying spatial dependency in landscape genetic studies. Ecography 31:685-697 https://doi.org/10.1111/j.1600-0587.2008.05428.x

Nacoulma-Ouedraogo O (1996) Plantes médicinales et Pratiques médicales traditionnelles au Burkina Faso: cas du plateau central. Tome I. Thèse de Doctorat d'Etat ès Sciences Naturelles. Université de Ouagadougou, $320 \mathrm{p}$

Nikiema A (2005) Agroforestry parkland species diversity: uses and management in semi-arid West Africa (Burkina Faso). PhD Thesis Wageningen University, $102 \mathrm{p}$

Nombré I, Schweitzer P, Sawadogo M, Boussim IJ, Millogo-Rasolodimby J (2009) Assessment of melliferous plant potentialities in Burkina Faso. African Journal of Ecology, 47, 622-629 https://doi.org/10.1111/j.1365-2028.2009.01034.x

Odebiyi JA, Bada SO, Omoloye AA, Awodoyin RO, Oni PI (2004) Vertebrate and insect pests and hemi-parasitic plants of Parkia biglobosa and Vitellaria paradoxa in Nigeria. Agroforest Syst 60: 51-59 https://doi.org/10.1023/b:agfo.0000009404.96034.58

Ognatan K, Adi K, Lamboni C, Damorou J-M, Aklikokou KA, Gbeassor M, Guilland J-C (2011) Effect of dietary intake of fermented seeds of Parkia biglobosa (Jacq) Benth (African locust bean) on hypertension in Bogou and Goumou-kope areas of Togo. Tropl J Pharm Res 10:603-609 https://doi.org/10.4314/tjpr.v10i5.9

Omojola MO, Afolayan MO, Adebiyi AB, Orijajogun JO, Thomas SA, Ihegwuagu NE (2011) Further physicochemical characterization of Parkia biglobosa (Jacq.) Benth fruit pulp as a mineral supplement. African Journal of Biotechnology vol. 10(75)17258-17264. https://doi.org/10.5897/ajb11.1625

Oni PI (2004) Initial evaluation of Parkia biglobosa (Jacq. Benth) provenances from West African countries. Workshop on plant genetic resources and food genetic resources and food security in west and Central Africa. IPGRI, 108 115

Ouedraogo AS (1995) Parkia biglobosa (Leguminosae) en Afrique de I'Ouest: Biosystématique et Amélioration. Dissertation, Wageningen University, Institute for Forestry and Nature Research, IBN-DLO, 205 p

Ouedraogo M (2015) Improving and conserving sahelian fruit trees: a case study of Parkia biglobosa (jacq.) Benth. IGN PhD March 2015. Department of Geosciences and Natural Resource Management, University of Copenhagen, Frederiksberg. $107 \mathrm{p}$

Ouedraogo M., Raebild A, Nikiema A, Kjaer ED (2012) Evidence for important genetic differentiation between provenances of Parkia biglobosa from the Sudano-Sahelian zone of West Africa. Agroforest Syst 85:489-503 https://doi.org/10.1007/s10457-011-9463-7

Pettersson S, Knudsen JTK (2001) Diurnal and populational variation in floral scent composition in bat pollinated Parkia biglobosa (Mimosaceae). Bot $J$ Linn Soc 135: 97-106

Pettet A (1977) Seasonal changes in nectar-feeding by birds at Zaria, Nigeria. Ibis 119: 291-308. https://doi.org/10.1111/j.1474-919x.1977.tb08249.x

Pollegioni P, Woeste KE, Chiocchini F, Olimpieri I, Tortolano V, Clark J, Hemery GE, Mapelli S, Malvolti ME (2014) Landscape genetics of Persian walnut (Juglans regia L.) across its Asian range. Tree Genet Genomes 10:1027-1043 https://doi.org/10.1007/s11295-014-0740-2

Ræbild A, Hansen UB, Kambou S (2012) Regeneration of Vitellaria paradoxa and Parkia biglobosa in a parkland in Southern Burkina Faso. Agrofor Syst 85: 443-453. https://doi.org/10.1007/s10457-011-9397-0

Ræbild A, Larsen AS, Jensen JS, Ouedraogo M, De Groote S, Van Damme P, Bayala J, Diallo BO, Sanou H, Kalinganire A, Kjaer ED (2011) Advances in domestication of indigenous fruit trees in the West African Sahel. New For 41:297315. https://doi.org/10.1007/s11056-010-9237-5
Rink, G., Carroll, E.R., Kung, F.H. 1989. Estimation of Juglans nigra L. mating system parameters. Forest Science 35: 623-627

Sanou H, Lovett N, Bouvet J-M (2005) Comparison of quantitative and molecula variation in agroforestry populations of the shea tree (Vitellaria paradoxa C.F. Gaertn) in Mali. Mol Ecol 14: 2601-2610 https://doi.org/10.1111/j.1365-294x.2005.02601.x

Schneider SS, Hall HG (1997) Diet selection and foraging distances of African and European-African hybrid honey bee colonies in Costa Rica. Insectes Soc 44:171-187. https://doi.org/10.1007/s000400050039

Schweitzer P, Nombre I, Kwame A, Boussim JI (2014) Spectrum of plant species foraged by Apis mellifera adansonii Latreille in the North Sudanian phytogeographical region of Burkina Faso. Grana 53:62-68 https://doi.org/10.1080/00173134.2013.853830

Sina S (2006) Reproduction et Diversité Génétique chez Parkia biglobosa (Jacq.) G. Don. PhD thesis Wageningen University, the Netherlands, $102 \mathrm{p}$

Teklehaimanot Z (1997) Germplasm conservation and improvement of Parkia biglobosa (Jacq.) Benth. For multipurpose use. Final report of EU-INCO research contract TS3*-CT92-0072, 1993-97. University of Wales, Bangor

Teklehaimanot Z (2004) Exploiting the potential of indigenous agroforestry trees: Parkia biglobosa and Vitellaria paradoxa in sub-Saharan Africa. Agrofor Syst 61:207-220. https://doi.org/10.1023/b:agfo.0000029000.22293.d1

Whitlock MC, McCauley DE (1999) Indirect measures of gene flow and migration: Fst $\neq 1 /(4 \mathrm{Nm}+1)$. Heredity 82:117-125. https://doi.org/10.1038/sj. hdy. 6884960 